\title{
Review
}

\section{Among the New Books}

\section{N. JAMEs with Neil Brodie, Simon Stoddart and Helen STRudwick}

Among our highlights this quarter are the monumental Barrington atlas and a little historical ethnography of Social complexity in the making, reviewed under 'Greeks and Romans' and the first section, respectively. A notable theme is theory and methods for tracing identity - to be found not only in the section on 'Discovering' but also in 'Theory', next, 'Cyprus and the Aegean' and 'Medieval \& Roman Britain'. More dubiously, shamanism is popping up all over the world, including among the ancient Greeks and Saxons.

\section{Theory}

CORNELIUS Holtorf \& HÅKan Karlsson (ed.). Philosophy and archaeological practice: perspectives for the 21st century. viii+320 pages, 31 figures. 2000. Lindome: Bricoleur; 91-9737-13-0-0 paperback £16, US\$27 (discounts for students).

Messrs HOLTORF \& KARLSSON present a set of seven reflections on doing archaeology, three on understanding the past, and another three which tack between present practice and past lives. Most contributors address themselves to thinkers in other disciplines (Heidegger, Wittgenstein, Merleau-Ponty, Foucault, Derrida, Giddens, Luhmann et al. - i.e., not only philosophy). Some are more perceptive than others: where K. Berggren, mulling over J. Butler and G. Spivak, retains the 'subject/object' distinction, Dr KARLSSON explains again the revelatory potential of recognizing ourselves as part of the world's 'Being' - although there is no hint as to how this can work in practice! C. Fowler criticizes assumptions about individuals as historical agents in favour of other modes of 'social being' ( $c f$. FRAZER \& TYRRELL in 'Britain', below). Its diversity is one of this book's delights. One of the surprises, for instance, is F. Criado Boado's assessment of implications in the thought of Lévi-Strauss; and O.W. Jensen examines cultural attitudes in Scandinavia, in the 19th and 20th centuries, as sources of disciplinary change (and see NOTELID in 'History', below).

A couple of papers on treacherous methodological ground are saved by wholesome case-studies of experimental interpretation in the field; but, in general, the editors seem not to have allowed room for worked examples. It is alarming to find a study on Feyerabend included but this is one of the papers on the practice of archaeology rather than on un- derstanding the past ... There, though, the reviewer reveals his own stance! In order to confirm the general impression, he checked the index for 'method' and found no mention. Nor does 'science' come into it, except in abhorrence. Other dogma is out, however; and there is every prospect, from these authors, of work to come which is both sensitive and sensible. They have largely eschewed wasteful intellectual sectarianism in order open-mindedly to reassess the interpretive and communicative possibilities. True to its principles, moreover, the book includes brief comments on the papers by other archaeologists and even authors' rejoinders. To read it really is like hearing a good earnest seminar.

DONALD TUZIN. Social complexity in the making: a case study among the Arapesh of New Guinea. xii+159 pages, 9 figures, 7 tables, 33 plates. 2001. London: Routledge; 0-415-22898-0 hardback $£ 45$, 0415-22899-9 paperback £13.99.

$\notin$ An older (but still breathing) school will find new inspiration in Prof. Tuzin's short ethnography and history of social change in the Arapesh-speaking village of Ilahita, New Guinea. Ilahita grew from 300 people or less, in the mid 19th century, to 1500 by the mid 20th. Seeking to explain how it managed this, Prof. Tuzin highlights three factors: territorial encroachment by Abelam people, encouraging security in numbers; dual social and ceremonial organization which proved capable of ramification; and adoption of the enemy's cult of war and sacrifice (only finally - and dramatically - abandoned in 1984). The cult depended on a hierarchy who supervised construction of immense temples and, in effect, ensured coherence through a transformation of the village's social organization. Prof. TuzIN remarks on how ethnographers 'could not disagree' with V.G. Childe and L.A. White 'so much as shrug in recognition of the unhelpful, tautological truth of thelir] generalization' (p. 5); but he claims now that 'Ilahita ... shows ... how scale and population dynamics might interact at an early stage of . . . complexity; how temples might sponsor settlement growth and political integration' (p. 125). Archaeological analogies spring strongly to mind although more thought is needed about how the Ilahita effect worked at larger social scales. Replete with reference to neoevolutionist and sociological theory and the likes of Jared Diamond, this book is a MUST. 


\section{Discovering cultural identities}

ROBERT A. SCHMIDT \& BARBARA L. VOSS (ed.). Archaeologies of sexuality. $\mathrm{xv}+303$ pages, 53 figures. 2000. London: Routledge; 0-415-22365-2 hardback $£ 60 \& \$ 90,0-415-22366-0$ paperback $£ 19.99 \&$ \$29.99.

JANE HuBERT (ed.). Madness, disability and social exclusion: the archaeology and anthropology of 'difference'. xvii+252 pages, 49 figures, 1 table. 2000. London: Routledge; 0-415-23002-0 hardback $£ 60$ \& $\$ 100$

RoBin TORRENCE \& ANNE CLARKE (ed.). The archaeology of difference: negotiating cross-cultural engagements in Oceania. xiii +418 pages, 72 figures, 32 tables. 2000. London: Routledge; 0-415-11766-6 hardback $£ 80$ \& \$130.

The first set of studies collected by SCHMIDT \& VOSS are on the organization of space: two on monasteries (Colonial California and R. Gilchrist on England), one on 'gay leathermen in San Francisco', and one on a novel of $c .1800$ ( $c f$. the section below on 'Spatial organization'). There follow four on 19thand 20th-century prostitution, homosexuality and Black midwifery in the USA and Australia; three case-studies in prehistory alongside a paper on architectural design and archaeological interpretations in the USSR ( $c f$. Gordon Childe in the following section); a couple on iconography (New Kingdom Egypt and the ancient Maya); and a concluding review by M. Conkey, remarking of Christopher Hawkes that 'he must be turning over in his grave, poor old guy!' (p. 289). It comes across well that identities may be created by subjects or imposed by others.

Ms HuBERT presents 16 studies of disability and exclusion from a great range of disciplines including archaeology and social and physical anthropology. Topical themes glow engagingly - including shamanism (in ancient Greece) and hermaphroditism (in early Modern Europe) - but, while each interesting in themselves, these papers are drawn from an even greater diversity of cultural settings and they hardly make a coherent collection.

The book on the impacts of contact with the Europeans and Japanese in Oceania works very well. TORRENCE \& CLARKE introduce eight studies of sites in Australia (including an interesting piece by CLARKE on Groote Eylandt, a paper on rock art, and a long study, by J. Birmingham, of foraging around a missionary site), a very sound case study of the dislocation of life in North Island, New Zealand (C. Phillips), and a couple each from Melanesia (including a satisfying analysis by Dr TORRENCE of change in artefacts) and Micronesia. Why, though, is the theme of subjective identity not explicit here? It is probably because, although the editors mention 'longterm processes' of 'negotiation' (p. 16), the articles are remarkable for focusing, in fact, on the sort of 'short term changes' (p. 176) traced by A. CLARKE. Americanists too will find this book rewarding; but it would be difficult to apply most of its lessons to prehistory.

\section{History of archaeology}

MicheL NoTELID. Dat andra påseendet: en studie av ôvergångar i den arkeologiska disciplinens historia (Occasional Papers in Archaeology 22) $x+217$ pages, 2 figures. 2000. Uppsala: Uppsala University Department of Archaeology \& Ancient History; 91-506-14363 (ISSN 1100-6358) paperback.

Charles Boewe (ed.). John D. Clifford's Indian antiquities; related material by C.S. Rafinesque. xxxvi+175 pages, 10 figures. 2000 . Knoxville (TN): University of Tennessee Press; 1-57233-099-6 hardback $\$ 30$.

Davina HuXley (ed.). Cretan quests: British explorers, excavators and historians. $x x i+227$ pages, 141 figures, 1 table. 2000. London: British School at Athens; 0-904887-37-5 hardback $£ 27$ (+p\&p).

JACEK LECH \& FRANCISZEK M. STEPNIOWSKI (ed.). $V$. Gordon Childe and archaeology in the 20th century. 496 pages, 63 figures, 1 table. 1999. Warsaw: Polish Scientific Publishers; 83-01-12862-3 paperback.

Awareness of the discipline's history is always very valuable for understanding what we are about. Its development in Scandinavia was especially important for the rest of the world. Dr NOTELID argues that, in the 19th century, the process there was an empiricist reaction to romanticism but that archaeologists also developed a sense of ethical responsibility. Yet he argues that, frustrated, archaeologists have struggled, since, both with projections of their own desires onto the evidence and the tantalising, essentially romantic concept of culture - how true. This book is most à propos HOLTORF \& KARLSSON, complementing O.W. Jensen in particular (see 'Theory', above). The book is in Swedish but has abstract and summary in English.

J.D. Clifford and C.S. Rafinesque pondered prehistory, monuments and finds in the USA, and the rest of the world, during the first half of the 19th century. They were in touch with leading archaeologists and Dr BOEWE considers that E.G. Squier plundered Rafinesque's manuscripts without acknowledgement. Assembling articles and correspondence by and to them, Dr BOEWE has revealed a telling mixture of speculation and observation. Clifford's ideas now look delightfully wayward but they are highly learned and motivated by as sweeping a historical imagination as the likes of A. von Humboldt or the 16th-century Spanish thinkers in Mexico upon whom he comments. Rafinesque compiled records of measured field monuments and undertook a lively review of Caleb Atwater's research.

The 22 papers assembled by Ms HuXLEY cover the history of British observations and research on Crete from the Middle Ages onward but concentrating on modern work and its changing emphases. The 
first part of the book is historical, the second and longer part considers themes of research by period. and the forms of evidence, along with contributions on the British School at Knossos (H. Catling) and on 'artists and craftsmen' (R. \& S. Hood). The book is well illustrated and produced elegantly and sturdily - with appropriate pride.

Confining themselves to archaeology as such, Dr LECH and 23 contributors from six countries (including several familiar to ANTIQUITY readers) assess Gordon Childe's contributions and effects - and five passages from his works are provided in an appendix. It is interesting to see contemporary responses to Childe's marxism from Poles. A.G. Sherratt remarks that Childe 'was . . . of his times, and should be celebrated as such' (p. 409). The papers are in Polish but brief summaries are provided in English.

See too our picture review of Images from the past.

\section{Methods and techniques}

E.B. BANNING. The archaeologist's laboratory: the analysis of archaeological data. xviii +316 pages, 162 figures, 15 tables. 2000. New York (NY): Kluwer Academic/Plenum; 0-306-46369-5 paperback $\$ 69.50$.

The archaeologist's laboratory is a comb-bound handbook 'to introduce students to basic laboratory and analytical techniques' (p. vii). 'What are data?' (covering 'Scales of measurement' and graphics), 'Systematics, compilations, and database design' (including hypermedia), 'Research design and sampling', 'Quantification' and 'Probability' are sensibly and sympathetically covered in highly detailed but clearly organized, labelled and illustrated sections, followed, with the same kind of treatment, by 'artifact conservation', 'Analysing lithics', and pottery and animal bones, plant remains, and 'Soils, sediments, and geomorphology'. There are sections on seriation and stratigraphy, on 'Interpreting radiocarbon dates', and on illustration. Each topic is presented with ample references. This book looks like a real boon. It has obviously benefited from drafts tested in the class room. Teachers will welcome it; 'Where's my Banning?!' will become a common cry among students; and it will be welcome among contract archaeologists and amateur groups too.

GARY LOCK \& KATE BROWN (ed.). On the theory and practice of archaeological computing. iv +154 pages, 22 figures, 3 tables. 2000. Oxford: Oxford University Committee for Archaeology; 0-94781651-8 paperback $£ 20$.

RAY A. Williamson \& PAUL R. NiCKEns (ed.). Science and technology in historic preservation. xxii+357 pages, 60 figures, 6 tables. 2000. New York (NY): Kluwer Academic/Plenum; 0-306-46212-5 hardback \$85.

LOCK \& BROWN introduce nine discussions of the state of the art, covering, in particular, virtual reality (VR) in research, archaeological archives, sites
\& monuments records, and aerial photography. There are also three general discussions. R.A. WILLIAMSON introduces 13 diverse but well-organized papers covering: remote and close sensing (including assessment of the Great Wall of China courtesy of NASA), dating methods, identification of materials' sources, and new techniques for working under water; preservation of wood and of materials from under water; and methods of preservation in situ, conservation and resource management, including protection by remote surveillance (not from space). For preservation, see too COLES et al. in the following section.

D.R. WILSON. Air photo interpretation for archaeologists (2nd edition). 256 pages, $123 \mathrm{~b} \& \mathrm{w}$ figures, 29 colour plates. 2000 . Stroud: Tempus; 0-7524-14984 paperback $£ 19.99 \& \$ 32.99$.

Mr WILSON's substantial guide has been improved with colour photographs. He hints that the new edition will be especially welcome in Central Europe where 'much progress has been made' (p. 13) since 1990 but where suitable publications are scarce.

\section{Environments}

BRyONY COLES, JOHN COLES \& MOgens Schou JøRGENSEN (ed.). Bog bodies, sacred sites and wetland archaeology: proceedings of a conference held by W.A.R.P. and the National Museum of Denmark, in conjunction with Silkeborg Museum, Jutland, September 1996. iii+236 pages, b\&w illustrations. 1999. Thorverton: Wetland Archaeology Research Project; 0-951-911-759; paperback; $£ 20(+£ 3$ postage).

GRAEME BARKER \& DAVID GILBERTSON (ed.). The archaeology of drylands: living at the margin. xxviii+373 pages, 116 figures, 21 tables. 2000. London: Routledge; 0-415-23001-2 hardback $£ 80$.

While the Profs. COLES \& Dr JøRGENSEN introduce 34 papers on discoveries, field techniques (including dynamite for sampling 'bog oaks') and procedures and methods of preservation from wetlands, Profs. BARKER \& GILBERTSON present 17 on the archaeology of coping with aridity. The wetland collection ranges from Somerset to Ireland and Denmark (with a stop for B. COLES on the Dogger Bank) and from the Swiss Lakes to Siberia, Japan and the Hoko River, Washington, where lessons from the Ozette site have been taken further. The drylands collection includes four papers on Asia (including the Negev and 'a 10,000 year landscape' study from Jordan by Prof. BARKER - cf. COINMAN in 'Palaeolithic', below), eight on Africa, a couple from the Americas, and two on western Europe (including 'dryland Switzerland'). Conditions in these regions have preserved evidence both of life in more clement conditions and of environmental change and adjustments. J.R. Parsons \& J.A. Darling, N.B., argue that cultivation of maguey (agave, aloe) was as critical for early agriculture in highland Central Mexico as animal husbandry in the Central Andes or the Middle East. 
Villagers near Padria pose above a Roman cistern for P.P. Mackey in 1899. PATRICIA OLIVO \& FRANGO STAFFA (ed.) have reproduced photographs of his in Images from the past: the archaeology of Sardinia at the end of the 19th century in the unpublished photographs of the Dominican Father Peter Paul Mackey (British School at Rome Archive 5: 237 pages, b\&w \& colour photographs n.d. (2000). Rome: British School at Rome; 88 7138-204-8 paperback) with new colour pictures of many of the same sites and essays on the man and the archaeology of the time and a note on Modern 'discovery' of the nuraghi. $A$. Crawford assesses Father Mackey as a photographer (highly) and writes that he was probably the vital inspiration for Thomas Ashby's archaeological research on Sardinia. Recent research has shown that the cistern remained in use until the late Middle Ages.

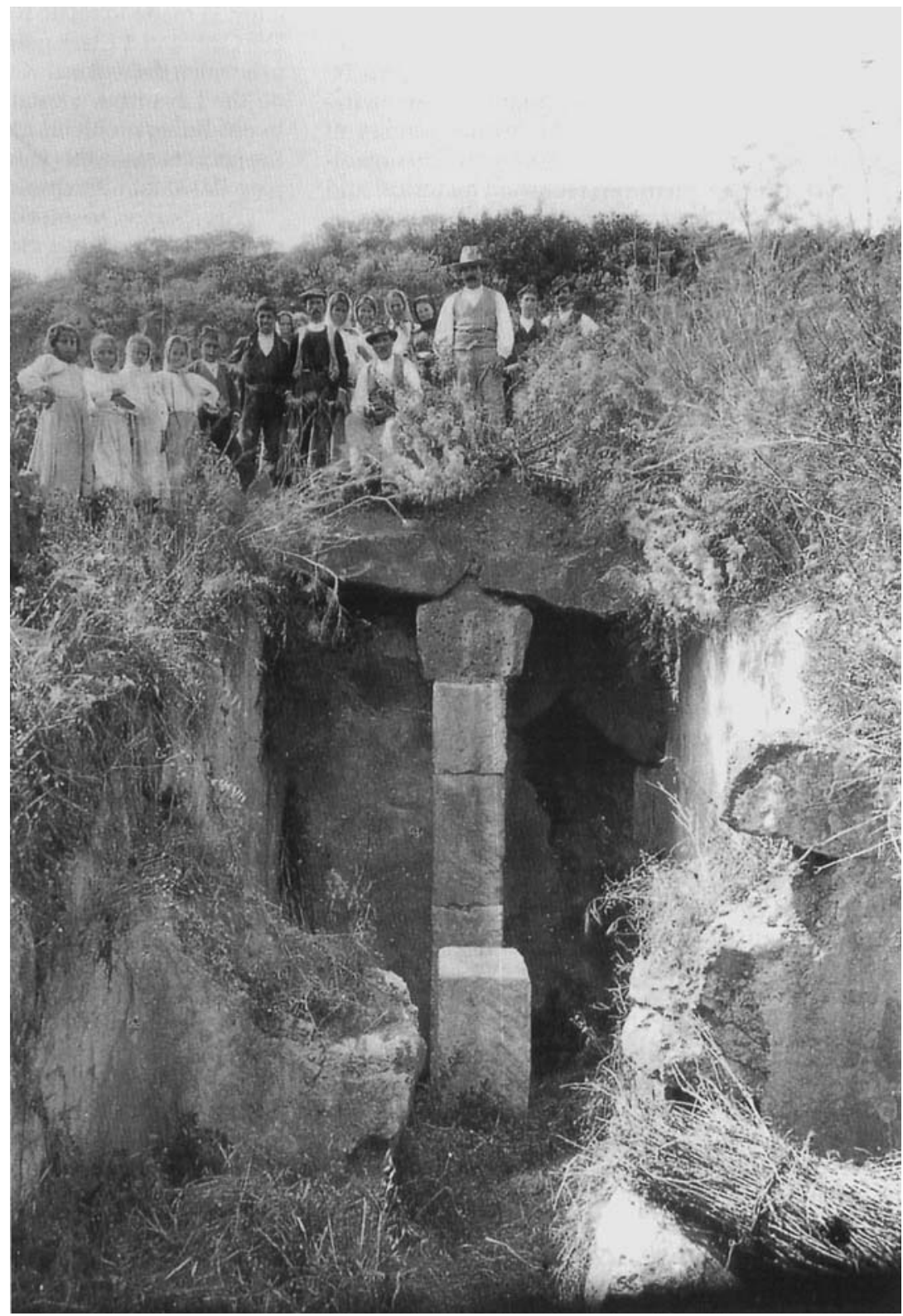

\section{World history}

Mogens Herman Hansen (ed.). A comparative study of thirty city-state cultures: an investigation conducted by the Copenhagen Polis Centre (Royal Danish Academy of Sciences \& Letters Historisk-filosofiske Skrifter 21). 636 pages, 95 figures, 8 tables. 2000. Copenhagen: Copenhagen Polis Centre; 8707876-177-8 (ISSN 0023-3307) hardback Kr600.

ELIZABETH J. MILLEKER (ed.). The Year One: art of the ancient world, east and west. xii +220 pages, 149 colour photographs \& figures. 2000. New York City
(NY): Metropolitan Museum of Art; 0-87099-961-3 (0-300-08514-1 Yale University Press) hardback £35.

MARTHA LAMBERG-KARLOVSKY (ed.). The breakout: the origins of civilization (Peabody Museum Monographs No. 9). $\mathrm{xx}+131$ pages, 31 figures. 2000. Cambridge (MA): Harvard University; 0-87365-910-4 paperback.

Dr HANSEN has assembled essays by historians and archaeologists to assess the nature of 'city states' and consider the role of the cities in world history. They include 11 on the ancient and Classical world, 
six on the Middle Ages and early Modern period in Europe, seven case-studies from Asia, seven from Africa, and three from Mesoamerica. Not surprisingly, the diversity seems baffling; but, reviewing previous literature as well as his own assembly of contributions, and concentrating on political organization, Dr HANSEN identifies recurrent historical and geographical patterns and distinguishes city states proper from states which incorporated distinct urban communities. Allowance has to be made for problems of definition and commersurability between different studies - as Dr HANSEN is aware. He concludes that 'Republicanism and federalism' today 'stem from city-state cultures' (pp. 615-16). All but three of the papers are in English (two in French, one German). See too NeILs in 'Greeks and Romans' and MARTIN \& GRUBE in 'Mesoamerica', below.

The Metropolitan Museum marked the millennium with a beautifully produced survey of fine art around the world 2000 years ago - Year One illustrated from its own collection. The biggest proportion is devoted to the Roman Empire but South and East Asia are respectably represented too. The focus is on the objets but a few maps and photographs of monuments hint at context.

The breakout is based on pieces first published in the house magazine of the Harvard Anthropology Department and Peabody Museum. With an essay of the editor's on the history of thinking about the origins of civilization and one by M.T. Larsen on 'Orientalism and Near Eastern archaeology', it comprises seven chapters covering the Middle East, the Harappan and China (on the latter, both K.C. Chang and G.R. Willey) plus M. Hammond on IndoEuropean democracy, L. Schele on the Maya and D. Maybury-Lewis on dualism and secularism. These thought-provoking little pieces reward scholars and laity alike. Compare TuzIN in 'Theory', above.

\section{Palaeolithic}

NANCY R. COINMAN (ed.). Excavations at Middle, Upper and Epipaleolithic sites (The Archaeology of the Wadi al-Hasa, west-central Jordan Vol. 2; Arizona State University Anthropological Research Papers no. 52). xiv+391 pages, 143 figures, 170 tables. 1 plate. 2000. Tempe (AZ): Arizona State University; ISSN 0271-0641 paperback \$45.

William Davies \& RuTH Charles (ed.). Dorothy Garrod and the progress of the Palaeolithic: studies in the prehistoric archaeology of the Near east and Europe, xiv+282 pages, 68 figures, 12 tables. 1999. Oxford: Oxbow; 1-900188-87-2 £40.

Drs CoINMAN \& G.A. Clark introduce 18 reports on 16 years of excavations and survey of sites in the Wadi Hasa, ranging from Mousterian to Natufian. Most of the work concentrates on the successive stone tool assemblages in order to trace continuities and developments in ways of life and technology. Some effort is made to relate to other regions of Jordan and Drs COINMAN \& Clark point out that the research helps to broaden the regional view from its longstanding focus on the Levantine coastal districts. The authors' care in out-lining problems and issues remaining and arising helps to make this volume a valuable review. (Compare BARKER in 'Environments', above.)

The Garrod memorial Festschrift comprises 16 papers ranging from assessments of Prof. Garrod's heritage in the Levant and western Europe to reports of new research from the Zagros to Gibraltar and Britain (including radiocarbon from Cheddar, Brixham and Cresswell Crags and J. Kozłowski arguing for indigenous Aurignacian development in the Balkans). There are also several papers on the history of research (Devon; Glozel; the Levantine Aurignacian [A. BelferCohen \& O. Bar-Yosef]; Miss N.F. Layard [illustrated by a couple of very entertaining photographs]). The list of Prof. Garrod's publications is complemented by three pieces of garrodiana. below.

See too OLIVEIRA JORGE in 'Southwestern Europe',

\section{Egypt}

by Helen Strudwick

A.J. SPENCER. Excavations at Tell el-Balamun 19951998. 209 pages, 12 colour photographs, figures. 1999. London: British Museum Press; 0-7141-1933-4 paperback $£ 60$.

LISA GIDDY. Kom Rabi'a: the New Kingdom and post-New Kingdom objects (The Survey of Memphis Vol. II). $x v+485$ pages, tables, plates. 1999. London: Egypt Exploration Society; 0-85698-147-8 hardback.

SPENCER presents a synthesis of the results of work carried out over three seasons which have revealed the development of the temple from the 22nd dynasty onwards, together with traces of an earlier 18th dynasty structure. The book is well laid-out, with good illustrations, and there is a final section summarizing the excavator's present understanding of the site.

A large number of objects from well-dated contexts have been recovered at Kom Rabi'a, Memphis, and GIDDY is to be applauded to bringing these objects together in a detailed, well-illustrated publication which will be an extremely useful reference book for others working in the field. Unfortunately, presumably because it is intended as one of a series of publications on this site, no plans or sections are included to which one can refer in order to understand how the objects relate to one another, although very detailed locations are specified in the text. It is therefore imperative that the Egypt Exploration Society does not delay too long before producing the next volumes of publication from this site.

J.D. BOURRIAU, L.M.V. SMITH \& P.T. NICHOLSON. New Kingdom pottery fabrics: Nile clay and mixed Nile/marl clay fabrics from Memphis and Amarna. 
xvi+105 pages, 37 figures, 26 tables, 9 b\&w \& colour plates. 2000. London: Egypt Exploration Society; 085698-149-4 paperback.

BOURRIAU, SMITH \& NICHOLSON have produced a welcome follow-up to the earlier study by two of the authors (Journal of Egyptian Archaeology 78 [1992]) which dealt with marl fabrics from the same two sites. Detailed descriptions of the samples on which the work is based, graphs which provide a visual analysis of the results, and excellent photographs of sherd breaks and thin sections, should make this an invaluable tool for the ceramicist working in Egypt.

IAN SHAw (ed.). The Oxford history of ancient Egypt. $\mathrm{xv}+512$ pages, b\&w and colour illustrations. 2000. Oxford: Oxford University Press; 0-19-8150342 hardback $£ 25$.

Most of the present generation of Egyptologists will have grown up with Gardiner's Egypt of the Pharaohs, a work which related the history of Egypt in a continuous narrative by a single author. The new Oxford History looks as if it will provide a longoverdue replacement. Written by multiple authors, it does not suffer from Gardiner's sometimes rather narrow view, although some chapters are better than others. Those covering prehistory and the intermediate periods are particularly good, with Seidlmayer on the First Intermediate Period and Bourriau on the Second Intermediate Period outstanding. Bryan's chapter on the 18th Dynasty before the Amarna Period (unfortunately misspelled in the running heading) is also particularly good. Unfortunately, the Ramesside period is tacked on to the end of the following chapter and so does not really receive the attention it deserves. The approach combines traditional chronological history with cultural and social historical material to produce a well rounded picture. The only fly in the proverbial ointment is the lack of references for the interested scholar or student to follow up, which is very frustrating. An annotated bibliography is provided, but there is no consolidated booklist to make it really useful.

ANTHONY LEAHY \& JOHN TAIT (ed.). Studies on ancient Egypt in honour of H.S. Smith (Egypt Exploration Society Occasional Publication 13). vii+336 pages, 193 figures, 13 tables. 1999. London: Egypt Exploration Socicty; 0-85698-151-6 (ISSN 0265-4261) hardback.

Studies on Ancient Egypt is a collection of papers by friends and colleagues of Prof. Smith. The wide variety of subjects covered by this volume indicates Harry Smith's breadth of interest, from field archaeology to the translation of demotic papyri. Amongst the best papers are: John Baines' typically thought-provoking discussion of early private inscriptions as the forerunners of narrative biographies; Janine Bourriau's paper, which compares the textual evidence of the Kamose stela and the archaeological record for the same period; a comparison of potmarks from Karnak North and Amarna by Colin Hope which should fuel further study of this subject; and Stephen Quirke's interesting observations on the role of women. There is much here for all scholars to enjoy, not only the dedicatee.

SERGE SAUNERON. The priests of ancient Egypt (2nd ed.; tr. David Lorton). xiv+215 pages, b\&w photographs, 1 map. 2000. Ithaca (NY): Cornell University Press; 0-8014-3685-0 hardback £32.50 \& \$42.50, 0-8014-8654-8 paperback $£ 13.50$ \& $\$ 17.95$.

MiChel Chauveau. Egypt in the age of Cleopatra (tr. David Lorton). xii+226 pages, 44 figures, 1 table. 2000. Ithaca (NY): Cornell University Press; 08014-3597-8 hardback £32.50 \& $\$ 45,0-8014-8576-2$ paperback $£ 13.50 \& \$ 17.95$.

KAROL MYŚLIWIEC. The twilight of ancient Egypt: first millennium BCE (tr. David Lorton). xvii+232 pages, 64 figures, 1 table, 24 colour plates. 2000. Ithaca (NY): Cornell University Press; 0-8014-37164 hardback $£ 35.95$ \& $\$ 55,0-8014-8630-0$ paperback $£ 16.50$ \& $\$ 24.95$.

Three translations by David Lorton have been published by Cornell University Press. The English of these books reads very well on the whole. Perhaps the least good is SAUNERON's book, describing the role and importance of the priesthood. This is a very well known book, first published in 1957. This edition is based on the updated version of 1988 but it still remains a little dated and one wonders whether there was much to be gained from translating it, although it will undoubtedly be more accessible to the interested lay person. Egypt in the age of Cleopatra, on the other hand, is a valuable addition as there are few, if any, general publications on this period, and it provides a very readable and entertaining overview. Twilight of ancient Egypt was originally published in Polish. The English edition been translated from the 1998 German edition, Herr beider Länder, familiar to most Egyptologists. The English title is rather strange because, whilst the book presents a history of Egypt after the last traditionally 'great' era, the New Kingdom, from 1070 to $323 \mathrm{BC}$, it does so with an emphasis on the dualities prevalent in ancient Egypt. These dualities are reflected in the Polish and German titles; why then does is it not called Lord of the Two Lands? Although the bibliography has been updated, there are still some omissions, such as publications by Aston and Taylor. There are additional photographs in this edition, including several from recent Polish work in the field. However, with all three books, many of the photographs suffer because of the paper on which they are printed (as is sadly so often the case).

SIGRID HODEL-HOENES (tr. David Warburton). Life and death in ancient Egypt: scenes from private tombs in New Kingdom Thebes. xiii+329 pages, 215 colour and b\&w figures. 2000. Ithaca (NY): Cornell University Press; 0-8014-3506-4 hardback $£ 37.95 \& \$ 49.95$. 
It is hard to know how to categorise HODEL-HOENES' book, as its purpose is unclear. She begins by outlining the architectural and symbolic development of the well known 'Tombs of the Nobles' at Luxor. Then follows a fairly detailed description of the decoration of a number of these tombs. However, no real attempt is made to explain the meaning of this decoration, and the quality of the accompanying illustrations is variable, to say the least. This means that it is of little value as a reference book. However, it also claims not to be a guide book. The bibliography does not contain sufficient non-German literature to be accessible to a general English-speaking audience, and the book remains something of a disappointment.

Nicholas ReEves. Ancient Egypt: the great discoveries - a year-by-year chronicle. 256 pages, 234 colour illustrations, $363 \mathrm{~b} \& \mathrm{w}$ illustrations. 2000. London: Thames \& Hudson; 0-500-05105-4 hardback $£ 24.95$ \& $\$ 40$.

Although to all intents and purposes purely a 'coffee table book', ReEves has clearly put a great deal of research in and it should not be dismissed. Although one may wish to quibble about the 'greatness' of some of the discoveries cited, this book gives an excellent overview of the rediscovery of ancient Egypt and should be popular with the non-specialist. Egyptologists too will find it of great use.

[See too 'Reissued', below.]

\section{Cyprus and the Aegean}

by Neil Brodie

PAUL Åström. A century of international cyprological research. 47 pages, 8 plates. 2000. Nicosia: Bank of Cyprus Cultural Foundation; 996342-088-5 paperback.

JENNIFER M. WEBB. Ritual architecture, iconography and practice on the Late Cypriot Bronze Age. xii+369 pages, 94 figures, 4 tables. 1999. Jonsered: Paul Åström; 91-7081-148-2 paperback Kr400.

Studies in Mediterranean Archaeology (SIMA) have a penchant for Cyprus, no doubt because of the fundamental contribution made to the archaeology of that island during the 1920s and 1930s by the Swedish Cyprus expedition. The story of the expedition is recounted in $A$ century of international Cyprological research - the first in a rash of SIMA publications which provide a short but readable history of Cypriot archaeology. Whether the 19thcentury diggings of the Cesnolas and their ilk should qualify as research is hard to say but their inclusion is welcome nevertheless.

The SIMA 'pocket-book', Ritual architecture, iconography and practice, is a substantially revised version of the author's doctoral dissertation. It develops a 'polythetic contextual' methodology for the recognition of cult practice, which is then applied in a comprehensive study of the material remains of Late Bronze Age Cyprus. The systematic exami- nation of architecture, artefacts and iconography is situated within the on-going debate over Cypriot state formation, and the author concludes that her study offers support for the thesis that a single, islandwide state first appeared during the 16th century BC, with Enkomi as its paramount centre.

JAMES R. STEWART. Corpus of Cypriot artefacts of the Early Bronze Age (Eve Stewart [ed.] Part III: 1; Studies in Mediterranean Archaeology III:3). xvi+176 pages, 29 figures, 23 plates. 1999. Jonsered: Paul Åström; 91-7081-159-8 paperback Kr400.

ROSE MARY WASHBOURNE. Out of the mouths of pots: towards an interpretation of the symbolic meaning of Cypriot Bronze Age funerary artefacts including examples in the University of Canterbury's Logie Collection. $\mathrm{v}+393$ pages, 253 figures, 5 tables. 2000. Jonsered: Paul Åström; 91-7081-105-9 paperback Kr450.

Dimitri ANSON \& Barbara Huband. Corpus of Cypriot antiquities: Cypriote pottery in New Zealand collections (Vol. 19; Studies in Mediterranean Archaeology XX:19). 75 pages, 145 figures, 145 photographs. 2000. Jonsered: Paul Åström; 91-7081-194-6 paperback Kr300.

Before his death in 1962, JAMES STEWART had prepared a comprehensive corpus of Early Bronze Age Cypriot artefacts (mainly Red Polished Ware) based on material he studied at Lapithos and Vounos before World War Two, post-war visits to museum collections in Stockholm, Paris, Cyprus and Beirut, and excavations at Vasilia and Ayia Paraskevi. The work of publication has fallen to his wife, who has edited the present volume, the third instalment to date, which covers classes X-XIII of his typology, which are, respectively, Milk Bowls, Basins, Cream Bowls, and Bowls. Part of the material from Stewart's excavations at Ayia Paraskevi and Karmi - again, mainly Red Polished Ware - is now in the Logie collection of the University of Canterbury, New Zealand, and forms the basis of Out of the mouths of pots, another doctoral dissertation published as a SIMA 'pocket-book', which publishes the material and also presents an analysis of its symbolism. Funerary vessels, it is argued, with their direct links to female production, metaphorical links to biological reproduction, and their iconography of fertility, were agents of rebirth, while the ornamentation and iconography of Plank Figures suggests that they were intended as representations of the Near Eastern fertility goddess, Inanna-Ishtar. The final chapter traces the later metamorphosis of the Cypriot Inanna-Ishtar into the Greek Aphrodite. Another SIMA project is the ongoing publication of the Corpus of Cypriot antiquities, and the 19th fascicle describes Bronze and Iron Age material in New Zealand collections at the Auckland Institute and Museum, the Whanganui Museum, the Museum of New Zealand Te Papa Tongarewa in Wellington, the Canterbury Museum in Christchurch and the Otago Museum in Dunedin. 
Paul Åström \& Dietrich Sürenhangen (ed.). Periplus: Festschrift für Hans-Günter Buchholz zu seinem achtzigsten Geburtstag am 24. Dezember 1999 (Studies in Mediterranean Archaeology CXXVII). 276 pages, 129 figures, 175 photographs, 60 tables. 2000. Jonsered: Paul Åström; 91-7081-101-6 hardback Kr800.

Hans-Günter Buchholz is another doyen of Cypriot archaeology, but as the bibliography in Periplus, a Festschrift presented to him on the occasion of his 80th birthday, makes clear, his scholarship ranges wider still, and is matched by the 22 contributions to this volume which touch upon many aspects of Bronze and Iron age East Mediterranean archaeology.

W.G. Cavanagh, M. Curtis, J.N. Coldstream \& A.W. Johnston (ed). Post-Minoan Crete: proceedings of the first colloquium. 134 pages. 69 figures, 5 tables. 1998. London: The British School at Athens; 0-904887-29-4 hardback $£ 22$.

J.A. MacGILLIVRAY, J.M. DRIESSEN \& L.H. SACKETT (ed.). The Palaikastro kouros: a Minoan chryselephantine statuette and its Aegean Bronze Age context (British School at Athens Studies 6). 239 pages, 39 figures, $31 \mathrm{~b} \& \mathrm{w}$ plates, 13 colour plates, 1 table. 2000. London: British School at Athens; 0904887-35-9 hardback $£ 43(+p \& p)$.

The British School at Athens (BSA) has recently launched a new Studies Series which will present conference proceedings and recent research in all areas of Greek studies. Post-Minoan Crete is Volume 2. It contains 16 papers from the First Colloquium on Post-Minoan Crete, held in London in 1995. The topics covered range in date from Sub-Minoan through to Roman and there are studies of iconography, architecture, coins, and also information culled from two regional surveys (Praisos and Sphakia). These are welcome contributions to the study of Crete at a time (from the 8th century BC at least) when, politically and economically (and culturally too), the island was very firmly part of the larger east Mediterranean world.

Q The Palaikastro 'Kouros', as it is called, was recovered between 1987 and 1990, in fragments, from burnt destruction layers of Late Minoan (LM) IB date (c. $1475 \mathrm{BC}$ ) at Palaikastro, in east Crete. It is a unique creation: a composite statuette, about $0.5 \mathrm{~m}$ tall, made on Crete, perhaps locally, but in part from imported materials, and under the cultural influence of New Kingdom Egypt. The main body of the statuette which betrays a surprising attention to anatomical detail - was constructed from eight pieces of hippopotamus ivory held together by small wooden dowels. The head was carved from serpentine, with inlaid, rock crystal eyes, and there is additional ornament of gold and Egyptian blue. The Palaikastro kouros tells the story of its discovery, excavation, conservation, original construction and subsequent restoration. But who was the Kouros? It was probably discovered in a town shrine, close to a store- room which was full of grain at the time of the town's destruction, and the excavators argue, convincingly, that the Kouros was a personification of Diktaian Zeus or Orion, set up to watch over the successful harvest.

William Cavanagh, Joost Crouwel, R.W.V. CATLING \& Graham ShIPLEY. Continuity and change in a Greek rural landscape - the Laconia survey (Volume 2): Archaeological data. (Annual of the British School at Athens Supplementary Volume 27.) $x x x+558$ pages, 22 plates, 200 illustrations, 8 tables, 3 maps. 1996. London: British School at Athens; 0904887-23-5 hardback $£ 58.50$ ( $£ 52.50$ to individual subscribers and Friends).

The Laconia Survey was carried out, from 1983 to 1988 , north and east of the Archaic/Mycenaean site of the Menelaion. Continuity and change is Volume 2 of the publication (Volume 1 has yet to appear) and, in the words of the Preface, contains a 'repertorium of ... data', which includes chapters on the pottery of all periods (Neolithic through to Ottoman), small finds, chipped and ground stone, architectural and sculptural fragments, epigraphic material, and also an account of the phosphate and geophysical surveys. The volume contains a catalogue of sites located during the Survey together with a valuable gazetteer of archaeological sites in the wider region of Laconia. Volume One will present analyses and interpretations of the now published data. [See also our picture review of Contingent countryside; and $c f$. the review in ANTIQUITY 73: 69091.]

LOUISE A. HITCHCOCK. Minoan architecture: $a$ contextual analysis. 272 pages, 33 figures. 2000. Jonsered: Paul Âström; 91-7081-192-X paperback $\mathrm{Kr} 400$.

Minoan Architecture is another SIMA 'pocketbook', and again publishes the author's dissertation. It starts with a brave critique of the practice of Minoan archaeology, and then offers a contextual analysis of what the author calls Minoan 'megastructures', thereby attempting not to impose a preconceived structure onto the Minoan palatial-style architecture which is the object of study. The book is heavily laced with 1980 s post-processualism but its approach is valid nonetheless: it argues that the meaning and function of both artefacts and architectural features are not fixed, but relational, or contextual, so that their interpretation must rely upon patterns of association. It also emphasizes the structuring interplay between everyday practice and the built environment. Despite the book's basic, relational, premise, the enquiry has need of a departure point, and architecture is chosen, with chapters that consider, respectively, courts and entryways, storage areas and workshop spaces, and, finally, halls. The author hopes to have provided a more nuanced and open-ended view of Minoan architecture. 


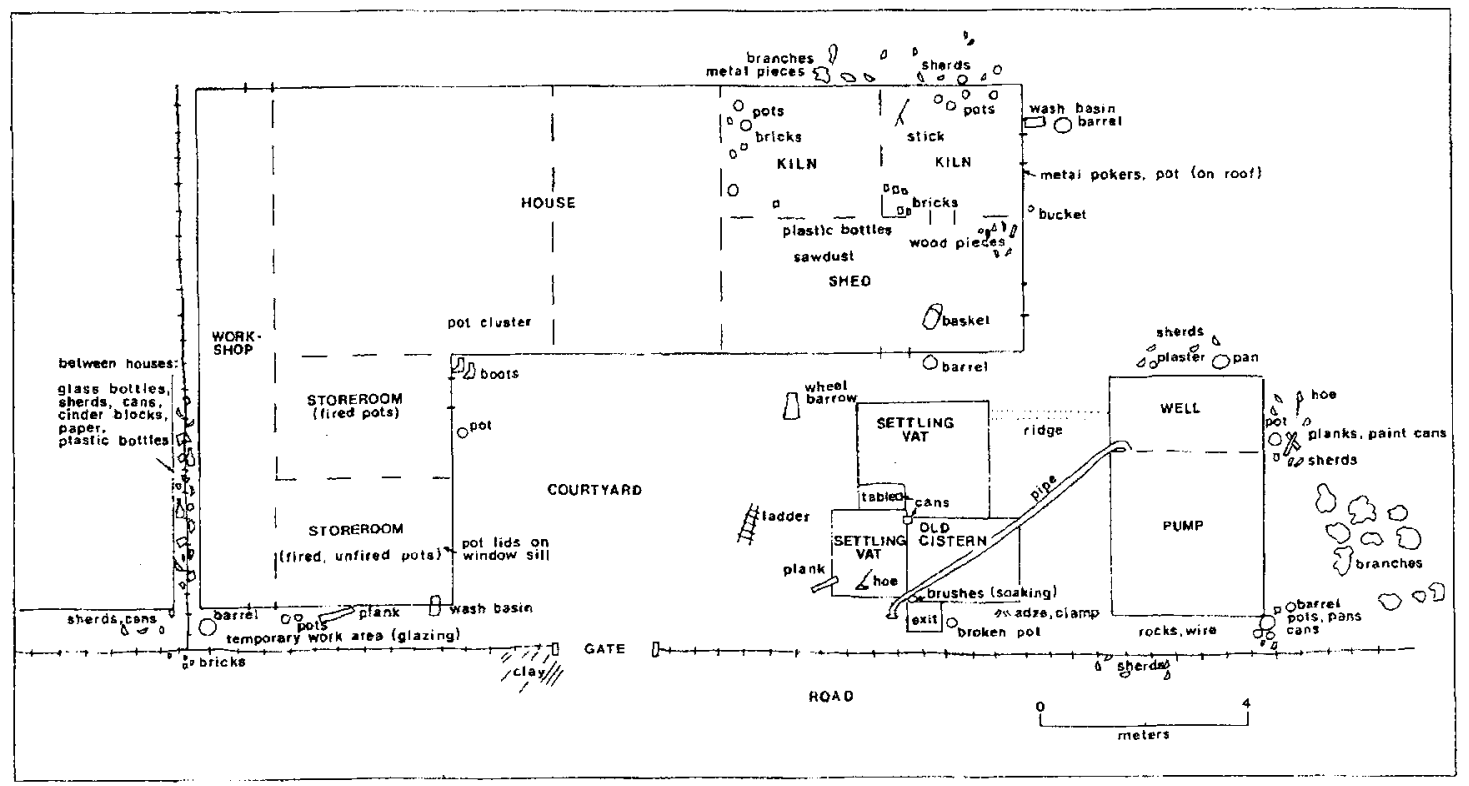

This detailed plan of a potter's workshop by P.N. Kardulias illustrates the ethnoarchaeological value of Contingent countryside: settlement, economy, and land use in the southern Argolid since 1700 (SUSAN BUCK SUTTON (ed.). xiv+391 pages, 57 figures, 50 tables. 2000. Stanford (CA): Stanford University Press; 0 -8047-3315-5 hardback $\$ 85 \&$ \&52.50). His study is one of seven ethnographic papers assembled with another seven historical reconstructions and all introduced by Prof. SUTTON on the theme of 'past and present in rural Greece'. They range from craft production to the history of population shifts, landholding and households' responses. Dr Kardulias also contributes to a detailed survey of modern agricultural, industrial and religious sites which showed both similarities to and differences from the ancient landscape.

ERIK Hallager \& BirgitTa P. Hallager (ed.). The Greek-Swedish excavations at the Agia Aikaterini Square Kastelli, Khania 1970-1987: the Late Minoan IIIC settlement (Vol. II: Text \& Plates) (Skrifter Utgivna av Svenska Institutet i Athen $4^{\circ}$ XLVII: II; Acta Instituti Atheniensis Regni Sueciae ser. in $4^{\circ}$ XLVII: II). 348 pages, 414 figures, 25 tables. 2000. Jonsered: Paul Åström; 91-7916-041-7 (ISSN 0586-0539) hardback Kr600.

The Greek-Swedish excavations is the second in a planned series of seven volumes which will publish the results of this important project in west Crete. In this volume there is a full description and discussion of the excavation of parts of this Minoan settlement which was rebuilt towards the end of the LM IIIB period and apparently abandoned (in orderly fashion) sometime early in LM IIIC.

IMMA KILIAN-DIRLMEIER. Das Mittelbronzezeitliche Schachtgrab von Ägina. (Alt- Ägina 4(3), Kataloge vor-und frühgeschichtlicher Altertïmer 27) 182 pages. 26 colour plates. 1997. Mainz: Philipp von Zabern; 3-8053-1992-4 hardback.

William Cavanagh \& Christopher Mee. A private place: death in prehistoric Greece (studies in Mediterranean archaeology 125). xiv +258 pages. 127 figures, 5 tables. 1998. Jonsered: Paul Åströms Förlag; 91-7081-178-4 paperback Kr 500.

Das Mittelbronzezeitliche Schachtgrab von Ägina publishes the important Middle Helladic II burial of an adult male (presumably a warrior) in a shaft grave at Kolonna, on Aegina. There are detailed accounts of the associated artefacts (which include a gold diadem and the remains of a boar tusk helmet) with a full discussion of contemporary comparanda and a final consideration of the burial's wider significance.

A private place is a corpus and analysis of the prehistoric burials of Greece. It collates material from the Greek mainland as far north as Thessaly up to the end of the Middle Bronze Age, when its coverage extends to include the Aegean islands of the Late Bronze Age Mycenaean koine, although not Crete. The main substance of the book is in six chapters arranged chronologically. Each presents a catalogue of all known burials of the period, together with a full discussion of grave architecture and funerary practices. The two final chapters, on ritual and social identity, provide a theoretical framework and examine the changing inter-relationships between ritual, society and culture. 


\section{Southwestern Europe}

Antonio ARNAIZ-VILlena. Prehistoric Iberia: genetics, anthropology, and linguistics. xii+252 pages, 31 figures, 29 tables. 2000. New York (NY): Kluwer Academic/Plenum; 0-306-46364-4 hardback \$90 \& $£ 62.25$ \& NLfl210.

Vítor Oliveira Jorge (ed.). $3^{\circ}$ Congresso de arqueologia peninsular, UTAD, Vila Real, Portugal, Setembro de 1999, uma organizaçao ADECAP-UTAD: actas (2 vols.). 1102 pages, figures, tables. 2000. Oporto: ADECAP; 972-97613-2-9 (Vol. 1), 972-976133-7 (Vol. 2) paperback.

From a meeting in 1998, Prehistoric Iberia comprises four papers on genetics (one reviewing the history of the whole Mediterranean basin, the others assessing connections with Africa, including the Berbers), one on the origins of Berber society, one (J.L. Escacena pondering implications of excavation at La Marismilla) on the possibility of African immigrants $c .5000 \mathrm{BP}$ - with implications for related origins of the Egyptians - and three devoted to language (including two on Basque, relating it to the 'Caucasian' \& Na-Dene languages). Papers from the 3rd Congress on Peninsular Archaeology (i.e. Spain \& Portugal; 1999) of the Association for Development \& Cooperation in Peninsular Archaeology (ADECAP) have been published in two sets: the first on the history of archaeological heritage management, archaeology \& society, history of archaeology (19 papers), and a miscellany; the second on the Palaeolithic (18 papers on the Lower \& Middle Palaeolithic, 10 on Upper Palaeolithic 'palaeoecology', and four on rock art). They are all in Spanish and Portuguese except two in English on the Middle Palaeolithic and six in English and one in French on the Upper Palaeolithic.

SandRINE CLAUDE. Le château de Gréoux-les-Bains (Alpes-de-Haute-Provence): une résidence seigneuriale du Moyen Âge l'Époque Moderne (Documents d'archéologie française 80). 191 pages, 151 figures, 2 tables. 2000. Paris: Maison des sciences de l'Homme; 2-73510801-5 (ISSN 0769-010-X) paperback F220 \& $€ 33.54$.

Michael D. Costen \& Catherine OAKes. Romanesque churches of the Loire and western France. 194 pages, 93 figures, 20 colour plates. 2000. Stroud \& Charleston (SC): Tempus \& Arcadia; 0-7524-1444-5 paperback $£ 17.99 \& \$ 29.99$.

Ms CLAUDE analysed the buildings of Gréoux-lesBains Castle in detail and has studied the archives for historical background. Her report is an absorbing case study with elements of landscape history and archaeology ( $c f$. KENNEDY in 'Reissued', below). Roll on summer with Romanesque churches (and cognac) to aid study on the ground! It explains the cultural and historical background as well as commenting on the buildings and ancillary features in detail. A gazetteer is provided. It is a pity that many of the black-\&-white photographs are a bit fuzzy.

\section{Greeks \& Romans}

RichaRD J.A. TALBERT (ed.). Barrington atlas of the Greek \& Roman world. xxxiii+249 pages, 100 maps, CD-ROM (Windows/Mac; or directory of xxi+1381 pages [2 volumes]). 2000. Princeton (NJ): Princeton University Press; 0-691-03169-X hardback £205 (£300 with directory).

The Barrington atlas is the biggest book to arrive here for years. The production is suitably superb - monumental. This is a 'publishing event'.

The maps cover the whole Classical world from Norway and Morocco to Tibet and the Bay of Bengal. They are at three scales: 1:5000,000 for the Mediterranean and Morocco, northwestern Europe, the Middle East, south Arabia, the Horn of Africa and Abyssinia and Kenya, the Himalayas, and South Asia; 1:1000,000 for the Greek and Hellenistic world, the mid Nile and the Roman world; 1:500,000 for the Aegean, the Levant, Italy, Provence, Cimmerius Bosphorus, and the Carthaginian heartland, Numidia and Mauretania; and 1:150,000 for Attica, Rome and its hinterland and the Bosphorus. The provinces and dioceses of the Roman Empire are mapped in an appendix.

Relief and elevation are indicated with contours and colours, and features from glaciers to reefs are marked in too. The labelling distinguishes place names ancient and modern. Cultural features are marked, including peoples, roads, walls, harbour works, aqueducts and canals, salt pans, and centuriation. Twenty-two distinct point symbols mark settlements - ancient and, where associated with archaeology, modern - tumuli, dams, water wheels, lighthouses, bridges and other features. Five colours are used to distinguish historical periods and a sixth marks multi-period features. Contemporary coasts are marked - Thanet shown as an island, for example. The detail is amazing: not only, for instance, is Duroliponte marked (Cambridge to barbarians) but also the villas, near-by, at Arbury, Exning, Wimpole, Litlington and Guilden Morden. Equally, empty quarters show most strikingly. South of the First Cataract, for example, beyond the Nile, the great pages show little except physical geography with gold mines, here and there, in telling isolation; and, again, a glance at Palmyra's setting reveals so much about the effort of living in that world. Limitations of knowledge are revealed more ironically by a glance beyond the German Limes, where the map gives no inkling of the pressures upon the Roman Empire.

The CD or directory provides commentary on each map and the present state of knowledge, along with references, where available, for every site marked and even lists of places and peoples known about but unlocated (lots in the East). Emphases are accounted for. For instance, the entry on Rome and its 
district explains that the map, marking roads and canals much more boldly than settlements, is selective perforce. The back-up information includes a complete index for the entire atlas.

The maps' details and contrasts could not show, of course, without clear printing. That has been achieved with an alluring elegance that can only be described as classical. The volume has been made sturdy enough to withstand generations of use. It is the work of 83 contributors, 95 reviewers and 16 technicians. It was 11 years in the making - good going - and cost US\$4.5 million.

Q Dissemination is an invaluable function for museums but few can afford to do it as well as in the next three titles. See too The Year One in 'World history', above.

ERIC M. MOORMANN. Ancient sculpture in the Allard Pierson Museum, Amsterdam (Collections of the Allard Pierson Museum 1). viii+334 pages, 16 figures, $96 \mathrm{~b} \& \mathrm{w}$ plates, 1 colour plate. 2000 . Amsterdam: Allard Pierson Museum 90-71211-32-0 hardback fl269.

C.M. STIBBE. Laconian oil flasks and other closed shapes (Laconian black-glazed pottery Part 3). 274 pages, 226 figures, 14 plates. 2000. Amsterdam: Allard Pierson Museum; 90-71211-33-9 hardback fl298.

MARION TRUe \& MARY LoUise HART (ed.). Greek vases in the J. Paul Getty Museum (vol. 6; Occasional Papers on Antiquities 9). ii+204 pages, 189 illustrations. 2000. Malibu (CA): J. Paul Getty Trust; 0-89236561-7 paperback $£ 34.50$.

THOMAS H. CARPENTER \& THOMAS MANNACK. Summary guide to Corpus Vasorum Antiquorum (2nd ed.). viii+100 pages. 2000. Oxford: Oxford University Press; 0-19-726203-1 paperback £9.95.

The Allard Pierson Museum's two books are admirable. Dr MOORMAN's very substantial catalogue raisonné presents 274 whole and fragmentary pieces ranging from Cycladic and Cypriot to Etruscan and Roman, including both freestanding and architectural sculptures, plus six pieces of doubtful attribution. For each, he provides notes on provenance, dimensions and description, a discussion, and references. Replete with excellent photographs, the book has been produced to the highest standard. Equally systematic and well illustrated and produced is the last part of Dr STIBBE's study of Laconian wares. Two long and detailed yet concise comparative discussions of pouring vessels and containers for storage and carriage, with a couple on other forms, are followed by a catalogue with brief descriptions and details of provenance and prior publication (if any) plus a catalogue of secondary painted ornamentation. Three indexes serve different ways to use the book. One or two Dutch infections of the spelling will help to make it a pleasure. The Getty Museum's Greek vases is a set of eight essays on whole and fragmentary pieces in the collection, including new identification of a painter through detailed analysis of iconographic composition (C.W. Neeft) and comparison with items in New York. Four are in English, three in German (including an amusing piece on symbolism in pictures from Italy) and one in Italian. Updated now are the helpful lists of collections of Attic figure-decorated pottery around the world (CARPENTER \& MANNACK).

$\notin$ Now, for the general reader, follows another trio on material culture which work together very well. They are followed, in turn, by three very satisfying books on intellectual culture and learning.

ROGER LING (ed.). Making Classical art: process and practice. 256 pages, 139 figures, 31 colour plates. 2000. Stroud \& Charleston (SC): Tempus \& Arcadia; 0-7524-1499-2 paperback $£ 19.99 \& \$ 32.50$.

J.G. LANDELS. Engineering in the ancient world (2nd ed.). 238 pages, 65 figures. 2000. London: Constable; 0-09-480490-7 paperback $£ 9.99$.

MANOLIS KORRES. The stones of the Parthenon (tr. D. Turner). 69 pages, b\&w illustrations. 2000. Los Angeles (CA): J. Paul Getty Museum; 0-89236-607-9 paperback $£ 10.95$.

Jenifer NeILs (ed). Worshipping Athena: Panathenaia and Parthenon $\mathrm{xi}+249$ pages, illustrations. 1996. Madison (WI): University of Wisconsin Press; 0-299-15110-7 hardback, 0-299-15114-X paperback.

Prof. LING and 10 colleagues explain for the nontechnical reader how sculpture, pottery and mosaics were made in the Classical world, including an account of work relations by Prof. LING. There follow 10 case-studies of monuments from wall paintings at Dura-Europos to the Parthenon and the Ara Pacis Augustae. This very approachable and absorbing book is a boon for VIth-form and introductory university courses as well as amateur aficionados. On pottery, compare our picture review of Contingent countryside. Making Classical art is complemented perfectly by Dr LANDELS's new edition; and, explaining the story of The stones of the Parthenon from quarry to construction and destruction, Mr KORRES' booklet (based on part of From Pentelicon to the Parthenon (1995)) is most satisfying too, appropriately illustrated with very elegant drawings.

Context for the Parthenon is provided by Prof. NEILS who has presented nine articles on myths and iconography of the cult of Athena and the associated rites and games along with one on the sensitively poised political scene of the mid $400 \mathrm{~s}$ in which, argues H.A. Shapiro, the goddess' festival expressed Pericles' rallying call to the Athenians. The combination of cultural history and studies of material culture (both sculpture and a couple of concise but rich papers on pottery) makes this book more than the sum of its parts.

JACQUES BRUNSCHWIG \& GEOFFREY E.R. LLOYD with PIERRE Pellegrin (ed.; tr. Rita Guerlac, Dominique Jouhaud, Catherine Porter, Jeannine Pucci, Elizabeth 
Rawlings, Anne Slack, Selina Stewart \& Emoretta Yang). Greek thought: a guide to Classical knowledge. xvii 1024 pages, 73 colour \& b\&w illustrations. 2000. Cambridge (MA): Belknap Press; 0-674-00261$\mathrm{X}$ hardback $\$ 49.95$.

ANNIE BonNAFÉ, JEAN-CLAude DECOURT \& BRUnO HELLY (ed.). L'espace et ses représentations (Travaux de la Maison de l'Orient Méditerranéen 32). 139 pages, 8 figures, 1 table. 2000. Lyon: Maison de l'Orient Méditerranéen; 2-903264-74-0 (ISSN 0766-0510) paperback F150 e22.87.

J.E. RAVEN. Plants and plant lore in ancient Greece (ed. William T. Stern). xxvii+106 pages, colour \& b\&w illustrations. 2000. Oxford: Leopard's Head Press; 0-904920-40-2 hardback.

DAVID BRAUND \& JOHN WILKINS (ed.). Athenaeus and his world: reading Greek culture in the Roman Empire. xxii +625 pages, 13 plates. 2000 . Exeter: University of Exeter Press; 0-85989-661-7 hardback £45.

$\Rightarrow$ Forty-seven authors from seven countries contribute to the encyclopaedia on Greek thought first published in French, English and Italian five years ago. They cover 62 topics grouped as philosophy, politics, the nature of knowledge, currents of thought, and major figures (19, in alphabetic order). The articles are very substantial but approachable, pithy and coherent. The book has been produced to suitable standards. It is outstanding value for the price. It is complemented by the six case studies in L'espace on ancient geographical descriptions in texts (including theatre) and maps, covering the Romans as well as the Greeks. The authors identify didactic and ideological effects as well as revealing the development of empirical description and explanation (compare the review of The first fossil hunters (pp. 239, below)). Turning back to Greek thought, it is surprising that the index lists just people, with themes and topics only appearing as sub-headings, but the book is organized clearly enough to lead one quickly to articles on 'geography', for instance, or 'images of the world'. J.E. RAVEN's Gray Lectures at Cambridge (1976) are accompanied by his lecture to the Alpine Garden Society (1971), notes by Alice Lindsell (1937) and appreciations of both authors' work by the editor and three others, including Peter Warren. The book is specialized but fascinating and most attractively produced.

Athenaeus, who, in the late 2 nd century AD, compiled a very large corpus of ancient literature which scholars have used extensively, has been too much taken for granted, considers Prof. BRAUnD. The 41 papers on Athenaeus by scholars from a dozen countries, assess the history of his texts, his assumptions and methods, his uses of Homer, Plato and other Greek authors and his principles of taste and ethics. No doubt, he remains unoriginal but Athenaeus is shown here as all the more valuable an exponent of the 'high culture' of his age.
SIMON HORNBLOWER \& TONY SPAWFORTH (ed.) Who's who in the Classical world. $\mathrm{xx}+449$ pages, 5 maps. 2000. Oxford: Oxford University Press; 0-19280107-4 paperback £8.99 \& US\$15.95.

APPIAN. Wars of the Romans in Iberia (tr. etc. J.S. Richardson). viii+184 pages, 5 maps. 2000. Warminster: Aris \& Phillips; 0-85668-719-7 hardback $£ 35$ \& US\$59.99, 0-85668-720-0 paperback $£ 13.25$, US\$22.

Suttonius. Lives of the Caesars (tr. Catharine Edwards). xlii+392 pages, 3 maps, 1 table. 2000. Oxford: Oxford University Press; 0-19-283271 paperback $£ 7.99$ \& US $\$ 11.95$.

Aesop and Zeno, Marc Antony and Virgil are among nearly 500 critical biographies in the Who's who, along with the likes of Hannibal and even Boudicca. APPIAN and SUETONIUS are now published in new translations.

See too HollowaY in 'Reissued', and Plotinus in 'Also received', below.

\section{Spatial organization in the later prehistory of Europe} by Simon Stoddart

MARTIN KUCKENBURG. Vom Steinzeitlager zur Keltenstadt: Siedlungen der Vorgeschichte in Deutschland. 216 pages, figures, 11 colour illustrations. 2000 . Stuttgart: Konrad Thiess; 3-8062-1446-8 hardback.

STEPHAN FichTL. La ville celtique: les oppida de 150 av. J.-C. à 15 ap. J.-C. 192 pages, b\&w figures. 2000. Paris: Errance; 2-87772-183-3 paperback F160.

EvŽEN NEUSTUPNÝ (ed.). Space in prehistoric Bohemia. 176 pages, 1 figure, 24 tables, 24 colour plates. 1998. Prague: Czech Republic Academy of Sciences Institute of Archaeology; 80-86124-09-6 hardback.

Three recent arrivals cover settlement, landscape and space in Continental Europe in various forms, languages and chronologies. KUCKENBURG provides a useful summary of Siedlungsarchäologie in Germany from the Stone Age to the post-Roman Iron Age. The author offers well-illustrated access to key sites (Bilzingsleben, Heuneburg, Manching) and landscapes (Aldenhovener Platte and the Federsee) by projecting important detail of key discoveries into the overall trends of prehistory. The book is well illustrated and concludes with tips on how to visit sites and museums, as well as a useful bibliography covering recent books in German and English. FICHTL covers a shorter chronological span and different geographical range. The central theme is the oppidum, and consequently the last 150 years of the Iron Age. A series of chapters define the term, and then analyse architecture, functions, environment (including some information of rural settlement) and the oppidum's demise. The geographical focus, although with reference to the centre and east of the oppidum range (e.g. some aspects of Manching and Zavist), draws more from the research in the western. French, zone. Again, this is a well illustrated source book 
where recent research, particularly on the more structural features of oppida, can be accessed. NEUSTUPNÝ is altogether more interpretative in feel, drawing together a series of case-studies and themes (events/ structures, memory) in pursuit of the 'social and ideological conditioning of spatial structures' (p. 7). These ideas are explored in terms of the experience of the authors (NEUSTUPNÝ, Venclova and Kuna) in Bohemia. Whereas the first two, from a Franco-German tradition, are broadly empirical in tradition, this last volume, from the Czech Republic, starts from the premise 'that any meaningful research project must include theoretical considerations from its very beginning' (p. 9).

\section{Medieval \& Roman Britain}

OLWYN OWEN, ANN MACSWEEN \& MATTHEW RITCHIE. The future of the Scottish Burgh Survey. $x+50$ pages, 24 figures, 7 tables. 2000. Edinburgh: Historic Scotland; 1-903570-15-8 paperback.

William O. Frazer \& ANDREW Tyrell (ed.). Social identity in early Medieval Britain. xiii +283 pages, 19 figures. 2000. London: Leicester University Press; 0-7185-0084-9 hardback $£ 45$.

JULIAN D. RICHARDS. Viking Age England. 190 pages, 75 figures, 25 colour plates. 2000. Stroud \& Charleston (SC): Tempus \& Arcadia; 0-7524-1489-5 paperback £14.99 \& \$24.99.

The Scottish Burgh Survey began in 1976 and, in 1999, a questionnaire was circulated in order to assess awareness of the Survey and the pressures of forthcoming development among Scotland's oldest towns. The new report summarises the findings and concludes that there is a strong case for maintaining and developing the Survey.

Mr FRAZER introduces 11 substantial papers in history, archaeology, art history and physical anthropology which show the enlivening effect of cultural anthropology and social studies. Individual, social, political, regional, ethnic and national identities are explored. Many ANTıQUITY readers will be drawn first to two pieces: T. Saunders' consideration of settlement planning and early towns in England, which takes the risk of assessing feudalism as relations of social class; and S.T. Driscoll's study of Christian monumental sculptures in Scotland. However, the book succeeds in drawing the attention to suggestions from other disciplines - do not be put off by C. Knüsel \& K. Ripley on the shamanism wagon in their sturdy account of paradoxical associations of gender in graves. B. Yorke's contribution on historical evidence for pragmatic political affiliations could also profitably be read by students of other societies ( $c f$. HANSEN in 'World history', above). Viking Age England is a substantial revision of Dr RICHARDS' book of 1991, updating with new information (NB the passage on the cemeteries at Heath Wood and Repton) and theory (new emphases on political, economic and cultural identity - 'Viking England was a melting pot' (p. 169)). The text has been reorganized and jazzed up a bit; references have been introduced; and some of the pictures are different or improved along with more colour plates. (See also 'Reissued', below.)

BARRY CUNLIFFE. Boman Bath discovered (3rd edition). 105 figures, 28 colour plates. 2000. Stroud \& Charleston (SC): Tempus \& Arcadia; 0-7524-19021 paperback $£ 14.99 \& \$ 24.99$.

Prof. CUNLIFFE has benefitted from the same treatment as Dr RICHARDS. The main changes are a new first chapter on the setting, major revision of the chapter on the surrounding town and extra-mural development, and deletion of the short chapter on presentation for visitors.

\section{Mesoamerica}

Students of Mesoamerica can benefit from a couple of very substantial and thought provoking reports.

KazUO Aoyama. Ancient Maya state, urbanism, exchange, and craft specialization: chipped stone evidence from the Copan Valley and the La Entrada region, Honduras (University of Pittsburgh Memoirs in Latin American Archaeology 12). xxviii+227 pages, 91 figures, 85 tables. 1999. Pittsburgh (PA): University of Pittsburgh Department of Anthropology; 1877812-54-4 paperback.

ROBERT H. COBEAN \& Alba GUadalupe Mastache (ed.). Tepetitlan: a rural household in the Toltec heartland. 449 pages, 302 figures. 1999. Mexico City \& Pittsburgh (PA): Instituto Nacional de Antropología e Historia \& University of Pittsburgh; 970-18-11828 paperback.

Simon MARTin \& NiKOlai GRUBE. Chronicle of the Maya kings and queens: deciphering the dynasties of the ancient Maya. 240 pages, 86 colour illustrations, $300 \mathrm{~b} \& \mathrm{w}$ figures. 2000 . London: Thames \& Hudson; 0-500-05103-8 hardback £19.95.

The Acropolis at 9th-century Copán may have been littered with arrowheads, according to Dr AOYAMA - suggesting a violent end there, and reinforcing the proposition that the 'Maya collapse' was self-inflicted. He has assessed the stone tools recovered from both the Copán Valley and district to the northeast for all periods from Early Formative to Early Postclassic. His study of sources of the material seems to reveal development of economic control; and he confirms that, as in Yucatan and Belize, in the Early Postclassic, Central Mexican obsidian was more common than during the Early Classic - as though trade flowed more freely. Yet, while he allows that early leaders controlled other crafts, Dr AOYAMa thinks that specialization in knapping followed emergence of social ranking but did not foster it. However - while aware of doubts about the scale of production at other cities of the Classic period - he does think that Copán later 
enjoyed a flourishing obsidian industry and exported the produce. The report is in English and Spanish.

Drs COBEAN \& MASTACHE are right to point out that there is a dearth of excavations of rural sites of the Early Postclassic period in Central Mexico. During the past decade, the Mexican government sponsored a great deal of major research on towns of that period; but, after all, the great majority of people then were villagers. It is not surprising to learn that the housing investigated at Tepetitlan was similar to that in the great town of Tula, a few miles away but it is important to have it confirmed - and COBEAN \& MASTACHE do warn that there are other residential structures at the site which appear to be unlike the patio group that they dug. The bulk of the report is devoted to the finds, including bones, human and faunal (less rabbit than in the town), and plants (including a fragment of cacao - compare AOYAMA), with particular attention to maize (by B.F. Benz, who identified various kinds) - but the pottery leaves doubt as to whether tortillas were normal fare. COBEAN \& MASTACHE analyse the evidence for activity areas. The body of the report is in both English and Spanish but the technical appendices in Spanish only.

Congratulations to the authors and their publisher for making the new history of the Classic Maya so accessible to a wide readership. MARTIN \& GRUBE are strong contributors to the revolutionary decipherment of royal epigraphy and, here, sum up the tales that are now emerging. The authors include the latest - and more complicated - results of their assessment of links among the 'city states' (Dr GRUBE contributes to HANSEN ('World history', above)). The work is highly technical but readers are spared the methodological apparatus. The book complements that of L. Schele \& D. Friedel, $A$ forest of kings (1990 New York: Morrow), which was a popular success. The illustrations in this one are vivid, intense and insistent - so much so, indeed, that they distract from the narrative. After all, though, it is a very special story - it was riddled with ideology; and it tells us little about the majority of the Indians. That is where COBEAN \& MASTACHE and AOYAMA are so valuable.

NB too the review of BARKER \& GILBERTSON in 'Environments', above.

\section{Local beliefs}

ALISON SHERIDAN (ed.). Heaven and Hell and other worlds of the dead. 168 pages, colour \& b\&w illustrations. 2000. Edinburgh: NMS; 1-901663-41-8 paperback $£ 14.99$.

ANNE Ross. Folklore of the Scottish Highlands. 158 pages, 36 illustrations. 2000. Stroud \& Charleston
(SC): Tempus \& Arcadia; 0-7524-1904-8 paperback $£ 12.99$ \& $\$ 19.99$.

Dr SHERIDAN presents some six dozen lively and most attractively illustrated discussions of ethnographic, archaeological and documentary images from around the world and through history. As to be expected, Dr Ross' lively treatment of folklore - updating her previous book on the subject - is alert to monuments and finds.

\section{Reissued in paperback}

HugH KENNEDY. Crusader castles. xvi+221 pages, 25 figures, $81 \mathrm{~b} \& \mathrm{w}$ plates, 7 colour plates. Cambridge: Cambridge University Press; 0-521-79913-9 paperback $£ 12.95$.

R. Ross Holloway. The archaeology of ancient Sicily. xix +211 pages, 224 figures. 2000. London: Routledge; 0-415-23791-2 paperback $£ 19.99$.

EUPHROSYNE DOXIADIS. The mysterious Fayum portraits: faces from ancient Egypt. 248 pages, $150 \mathrm{b \& w}$ figures, 124 colour illustrations. 2000. London: Thames \& Hudson; 0-500-28217-X paperback £24.95.

MichaEl LAPIDGE, JOHN BlaIR, SIMON KEYNES \& DONALD SCRAgG (ed.). The Blackwell encyclopaedia of Anglo-Saxon England. xviii+537 pages, 21 figures, 24 plates, 12 maps. 2000. Oxford \& Malden (MA): Blackwell; 0-631-22492-0 paperback $£ 17.99$ \& US\$34.95.

GREGORY A. RUF. Cadres and kin: making a socialist village in west China, 1921-1991. xxi+250 pages, 23 figures, 3 tables. 1998. Stanford (CA): Stanford University Press; 0-8047-4129-8 \$18.95 \& $£ 11.95$.

The archaeology of ancient Sicily was reviewed in ANTIQUITY 65: 1011-12, Fayum portraits in ANTIQUTTY 70: 195, The Blackwell encyclopaedia in ANTIQUITY 73: 459-60.

\section{Also received}

ÉTIENNE ZANGATO. Sociétés préhistoriques et mégalithes dans le nord-ouest de la République Centrafricaine (Cambridge Monographs in African Archaeology 46, BAR International series S768). 225 pages, 126 figures, 56 tables. 1999. Oxford: Archaeopress; 0-86054-980-1 paperback $£ 30$.

MARGARET R. MILES. Plotinus on body and beauty: society, philosophy and religion in 3rd-century Rome. xii+214 pages. 1999. Oxford: Blackwell; 0-631-212744 hardback £55 \& US\$68.95, 0-631-21275-2 paperback £16.99 \& US\$28.95.

Alan Palmer. Napoleon and Marie Louise, the second empress. $\mathrm{xx}+268$ pages, 5 maps, figures. 2001. London: Constable; 0-09-479860-5 hardback £20. 